\title{
Industry Analysis - The First Step in Business Management Scholarly Research
}

\author{
P. S. Aithal \\ Srinivas Institute of Management Studies, Pandeshwar, Mangalore - 575001, INDIA \\ E-Mail: psaithal@srinivasgroup.com
}

Type of the Paper: Research Case Study.

Type of Review: Peer Reviewed.

Indexed In: OpenAIRE.

DOI: http://dx.doi.org/10.5281/zenodo.810347.

Google Scholar Citation: IJCSBE

\section{How to Cite this Paper:}

Aithal, P. S. (2017). Industry Analysis - The First Step in Business Management Scholarly Research. International Journal of Case Studies in Business, IT and Education (IJCSBE), 1(2), 1-13. DOI: http://dx.doi.org/10.5281/zenodo.810347.

International Journal of Case Studies in Business, IT and Education (IJCSBE) A Refereed International Journal of Srinivas University, India.

(C) With Authors.

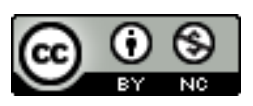

This work is licensed under a Creative Commons Attribution-Non Commercial 4.0 International License subject to proper citation to the publication source of the work.

Disclaimer: The scholarly papers as reviewed and published by the Srinivas Publications (S.P.), India are the views and opinions of their respective authors and are not the views or opinions of the S.P. The S.P. disclaims of any harm or loss caused due to the published content to any party. 


\title{
Industry Analysis - The First Step in Business Management Scholarly Research
}

\author{
P. S. Aithal \\ Srinivas Institute of Management Studies, Pandeshwar, Mangalore - 575001, INDIA \\ E-Mail : psaithal@srinivasgroup.com
}

\begin{abstract}
Industry analysis and Company analysis are two types of case study methods among many types of Case-based research analysis in Research Methodology. A case study based management research and teaching pedagogy are adopted by many business schools with the belief that it is a most powerful way to study and learn new lessons required to identify, understand, and solve the problems in the process of managing and leading the organizations. Analysing business cases of industries force students to grapple with exactly the kinds of situations, decisions, and dilemmas managers confront every day. Industry analysis is a powerful tool in developing both research case study and teaching case study in business management subject. Through industry analysis students and researchers can study various aspects of an industry and its components to enrich their knowledge in the core area of business including organizational management, environmental management, functional areas of business, strategic management, new idea generation as well as effective decision making. The issues or problems identified in a given industry and the efforts made by organizations to handle such issues or solve such problems are learning opportunities for students and researchers in business management institutions. In this paper, we have discussed the procedure of writing case studies based on industry analysis framework. We also recommend the Industry analysis as a class of case study methodology in management research for developing research case studies as a first step for budding researchers.
\end{abstract}

Keywords: Business case study, Case study as research methodology, Industry analysis, Industry analysis framework.

\section{INTRODUCTION :}

Systematic collection of data and analysing them with a purpose and interpretation of the results to enhance the knowledge about or improving the understanding of anything can be regarded as research. Research can also consist of analysing any system in terms of its inputs, processes, and output with an intention to study the internal/external factors affecting the system performance. System analysis is used as a research methodology to study any system in depth and can have both qualitative and quantitative components in it. An industry is a system consisting of a group of manufacturers or businesses with the common objective of producing a particular kind of goods or services. There are different types of industries and industry sectors with a number of firms doing business with profit motivation. While studying an industry or industry sector, one can use system analysis method so that industry analysis can be a part of the qualitative or quantitative research. In business management subject, analysing an industry or industry sector and analysing a company or firm are two fundamental methods of basic research methodologies. Though the research purpose in any field can be divided into exploratory, descriptive, explanatory, or policy oriented, these categories are not mutually exclusive, but they are a matter of emphasis. As any research study will change and develop over time, a researcher can identify more than one purpose in a system, research analysis on an industry have many purposes like to find its objectives, performance, procedure, problems, and strategies for sustainability. Industries are divided into many types with two major classes as manufacturing industries and services industries. The major aspects of business 
management, commerce, and economics subjects are revolving around these two types of industries, a systematic industry analysis can be helpful in identifying problems and developing innovative solutions and hence can contribute to new knowledge in these subjects.

\section{INDUSTRY ANALYSIS AS BUSINESS RESEARCH METHODOLOGY :}

Industry analysis is a type of case method research used to study an industry or industry sector with an objective to create new knowledge related to it. A good case study will include the problem, identify all the possible options to solve the problem of a system, and provides adequate information along with uncertainties to the decision-makers to choose which course of action will be best for the system. Industry and Company analysis are two types of Business case studies used to study the business model/issues of an industry or a firm systematically by identifying either research oriented issues and analysing them to create new knowledge or to learn a better way of solving the problems related to such issues. Accordingly, business case studies are used both in explorative research as a qualitative research method and teaching methods as teaching-learning pedagogy. The objective of research oriented case studies is to study and analyse a system to see new information to provide recommendations to expand the system or improve the performance of the system. The objective of teaching case studies is to learn the system for identifying the problems and to find optimum solutions to such problems using theoretical concepts. Both industry analysis and company analysis fulfil such objectives. The objective of research case studies may vary depending on the subjects like medicine, engineering, social science and business management. Research based case studies in business management may focus on analysing a single issue or many issues of an organization or an industry. These issues may relate to various aspects of the business and its environment. Even though the research case study is considered as a qualitative research method, many case studies collect large masses of quantitative data like performance data, profitability data, employment data, marketing data, etc. for a specific industry of an organisation. Research based case studies provide suggestions or recommendations to improve the system whereas teaching case studies pose some questions for the reader to analyse and recommend the solution. Analysing business cases of the industries and the companies force students to grapple with exactly the kinds of situations, decisions and dilemmas managers confront every day. A good industry analysis will include the problem, identify all the possible options to solve the problem, and provides adequate information along with uncertainties to the decision-makers to choose which course of action will be best for an industry or industry sector. Industry analysis based on a systematic procedure and objective can be used as a research based case study or teaching based case study. It is easy to develop both research case studies and teaching case studies compared to empirical research in many cases so that the students studying in higher education courses can develop case studies based on industry analysis as a part of their research project provided they collect required information of an identified systematically. In business management teaching institutions, analysing business cases of industries force students to grapple with exactly the kinds of situations, decisions, and dilemmas managers confront every day. Industry analysis is a powerful tool in developing both research case study and teaching case study in business management subject. In this paper, we have discussed the procedure of writing case studies based on industry analysis framework. We also recommend the Industry analysis as a class of case study methodology in management research for developing research case studies as a first step for budding researchers [1-15]. Industry analysis can be qualitative or quantitative research method based on nature of data and information collected from a given industry or group of industries. In many cases, industry analysis may deal large masses of data like performance data, employee data, profitability data, marketing data etc. of a specific organization or industry.

\section{TYPES OF INDUSTRY ANALYSIS :}

\section{(1) Industry Sector Analysis:}

An industry sector contains a segment of industries of a particular type in a given economy. Examples are materials sector, financial sector, food sector, energy sector, transportation sectors, health sector, education sector etc. A researcher can analyse such industry sectors by considering the common objectives, the challenges faced and the opportunities for them. An industry is a specific group of companies with very similar business activities. For example, financial sector can be broken 
into banking industry, insurance industry, assent management industry, etc. Thus while breaking down the given economy, the industry sectors forms a first set of groups which describe a general economic activity. Then all of the companies that fall into that sector are categorized further into industries where they are grouped only with companies with which they share very similar business activities. However, Industries can be further sub-categorized into various, more specific groupings. All the industries within an industry sector will be having same objectives but may follow different methods to realize their objectives. Researcher can try to identify what are the different types of industries lying within a given industry sector and also the different companies under each industry. In industry analysis, analysing an industry sector is like studying an organization's parent body. Studying the industry sector is essential in the process of analysing an industry because the objective of an industry is derived from its industry sector. Various analysis techniques like goal analysis, competitive analysis, SWOC analysis, PEST analysis and even ABCD analysis frameworks can be used in industry sector analysis [16-33]. Such analysis gives the idea to the researchers on possible further progress and constraints in that sector. The sector analysis of a given industry will guide the researcher while analysing the industry in hand.

Table 1 : Some popular sectoral list of industries

\begin{tabular}{|c|c|c|}
\hline S.No. & Industry Sector & Industries \\
\hline 1 & $\begin{array}{l}\text { Auto } \\
\text { Transportation } \\
\text { sector } \\
\end{array}$ & $\begin{array}{l}\text { Automobile industry, Aviation industry, Locomotive industry, } \\
\text { Shipping \& navigation industry, Tractor industry, Automotive } \\
\text { industry, Airline industry etc. }\end{array}$ \\
\hline 2 & Financial sector & $\begin{array}{l}\text { Banking industry, Insurance industry, Asset management industry, } \\
\text { Real estate industry, etc. }\end{array}$ \\
\hline 3 & $\begin{array}{l}\text { Consumer durables } \\
\text { sector }\end{array}$ & $\begin{array}{l}\text { Furniture industry, Jute industry, Leather industry, Paper industry, } \\
\text { Plastic industry, Rubber industry, Silk industry, Television industry, }\end{array}$ \\
\hline 4 & Textiles sector & Textiles industry, Garment industry, Weaving industry, \\
\hline 5 & $\begin{array}{lr}\begin{array}{l}\text { Fast } \\
\text { consumer } \\
\text { sector }\end{array} & \text { goving } \\
\end{array}$ & $\begin{array}{l}\text { Toothpaste industry, Soap industry, Biscuit industry, Cosmetics } \\
\text { care industry, Grocery industry, etc. }\end{array}$ \\
\hline 6 & $\begin{array}{l}\text { Electronics \& } \\
\text { information } \\
\text { technology sector }\end{array}$ & $\begin{array}{l}\text { Electronic communication industry, Information technology } \\
\text { industry, Computer industry, Audio \& video industry etc. }\end{array}$ \\
\hline 7 & Healthcare sector & $\begin{array}{l}\text { Bio-technology industry, Health care industry, Pharmaceutical } \\
\text { industry etc. }\end{array}$ \\
\hline 8 & $\begin{array}{l}\text { Metal \& mining } \\
\text { sector }\end{array}$ & $\begin{array}{l}\text { Aluminium industry, Copper industry, Diamond industry, Granite } \\
\text { industry, Mining industry, Pearl industry, Zinc industry, Steel } \\
\text { industry etc. }\end{array}$ \\
\hline 9 & $\begin{array}{l}\text { Oil \& Natural gas } \\
\text { sector }\end{array}$ & Oil industry \\
\hline 10 & $\begin{array}{lll}\begin{array}{l}\text { Energy } \\
\text { sector }\end{array} & \& & \text { power }\end{array}$ & idustry, Solar industry, Energy storage industries \\
\hline 11 & Service sector & $\begin{array}{l}\text { Advertisement industry, Electronic industry, Hotel industry, } \\
\text { Railway industry, Shipping industry, Telecomm industry, Tourism } \\
\text { industry, Transportation industry }\end{array}$ \\
\hline 12 & $\begin{array}{l}\text { Manufacturing } \\
\text { sector }\end{array}$ & Cement industry, Motor industry, Manufactured goods industry \\
\hline 13 & Retailing sector & $\begin{array}{l}\text { Cosmetic industry, Chocolate industry, Jewellery industry, Food } \\
\text { processing industry, Toy industry, Retail industry, Music industry, } \\
\text { Apparel industry, Grocery industry, etc. }\end{array}$ \\
\hline 14 & $\begin{array}{l}\text { Agriculture and food } \\
\text { sector }\end{array}$ & $\begin{array}{l}\text { Agriculture industry, Fertilizer industry, Food package industry, } \\
\text { Food processing industry, Irrigation industry, Agri-business } \\
\text { industries, Tobacco industry, Cotton industry, Dairy industry, } \\
\text { Poultry industry, Sugar industry, Tea \& Coffee industry, Beverage } \\
\text { industry, Fast food industry, }\end{array}$ \\
\hline
\end{tabular}




\begin{tabular}{|l|l|l|}
\hline 15 & Entertainment sector & Film industry, Music industry, Other entertainment industries \\
\hline 16 & $\begin{array}{l}\text { Construction \& } \\
\text { Housing sector }\end{array}$ & $\begin{array}{l}\text { Construction industry, Paint industry, Cement industry, Roofing } \\
\text { industry, Glass industry, }\end{array}$ \\
\hline 17 & Education sector & Training industry, Publication industry, Media industry \\
\hline 18 & $\begin{array}{l}\text { Other industry } \\
\text { sector }\end{array}$ & Printing industry, Coir industry. \\
\hline
\end{tabular}

(2) Industry Trend Analysis:

The present and future trend of a given industry are analysed in this stage. Based on changes in the economy, technology, environment, and people aspirations, the opportunity and the growth trend of an industry are affected. Industry trend analysis allows the researcher to predict the future performance of all companies of a given industry. The industry trend analysis also proposes the possible changes in business models and business scenarios in a given industry to encash available opportunities. Various operational research techniques, marketing research analysis, financial analysis, and yields, etc. can be used to analyse the industrial trends.

(3) Environmental Analysis :

This includes analysis of challenges and opportunities for the growth of industries based on environmental factors. This may also include internal industry environment and external factors affecting the industry.

\section{(4) Competitor Analysis:}

The completions within an industry forces companies to invest the major part of their resources, energy, smartness, and time to develop various strategies to out beat other companies within their industry. Studying the competitions of companies within a given industry and analysing it to know the effect of such competition on individual company performance as well as the overall performance of that industry. The competitor's analysis can be done as per the guidelines in Porter's 5 Forces Analysis [34-36]. This include

- Threat of new entrants to the given industry.

- Threat of substituent products or services or technology in that industry.

- Bargaining power of customers on pricing, quality, and after-sales support.

- Bargaining power of suppliers while supplying various resources in a given industry and the ability of companies to sustain and negotiate. The strength of bargaining power of supplier depends on their switching cost.

- The competition among the revelry in the given industry and its consequence on their profit and sustainability.

Researchers can also study the following generic competitive strategy of the companies within a given industry.

- Cost Leadership - the capacity of a company within a given industry to scale operations in order to offer lower prices than the majority of the players in that industry with an effort to maximize profits.

- Product or Service Differentiation - Through innovation, a company in a given industry can distinguish its product or service offers than those of the current cost leaders in the same industry and banks on standing out based on its newness factor.

- Industry Segmentation - A company or group of companies in a given industry may focus on a very specific or "niche" target market and focus on building traction with a smaller customer base first before moving on to the larger customer base.

- Newness in Industry - Satisfying a previously undiscovered need or want with no similar offering in a given industry.

- Better Performance - A company in a given industry strives to build something that is incrementally faster or better than what exists in the marketplace.

- Customization of Products or Services - How an industry and companies in it are able to offer customized products or services to each individual customer or customer segment.

- Better Design - How individual company offering is markedly better designed or stands out from the others in a given industry. 
- Price Comparison - How a company in a given industry offers the same product or service as everyone else at a lower price.

- Cost reduction - How a company business strategy in a given industry would help in decreasing the customers cost.

- Risk reduction - How a company business strategy help to reduce the risk its customers take when purchasing its products or services.

- Accessibility of Products or Services - How a company in a given industry tapped into a previously underserved or never served market.

- Convenience - How a company in a given industry offers something that's much easier to use than whatever else is in the marketplace.

(5) Alternative Product/service Analysis:

Industry analysis can also focus on finding alternative product/service to an existing product or service with various intensions like better features, better performance, better technology adopted, lower production cost, improved quality, reduced row materials \& other resources, reduced production processes, reduced production time, new distribution channels etc. Alternative products/service analysis may give rise to new innovative business models or processes in a given industry.

(6) Financial Performance Analysis:

The average financial performance of an industry in terms of overall investment in a given economy/country, in terms of initial investment, working capital and maintenance expenditure, the average return on investment, comparison of share prices, assessment of current position, prediction of current profitability \& growth prospects, and future investment opportunities \& returns have to be analysed. The researcher can also include the financial performance analysis of various companies working in the given industry. Financial performance analysis also include analysis and interpretation of financial statements of various companies working in that industry in such a way that it undertakes full diagnosis of the profitability and financial soundness of the business. Financial performance analysis also includes studying corporate capital structure decisions and the effective use of financial leverage in maximizing shareholder value while minimizing risk [37].

(7) Industry ABCD Analysis:

Various factors affecting the determinant issues in a given industry and their constituent critical elements of each factor can be determined by using ABCD analysis framework. These affecting factors are identified under the constructs advantages, benefits, constraints, and disadvantages of selected key issues.

\section{(8) Industry SWOC Analysis}

SWOC is an acronym for Strengths, Weaknesses, Opportunities and Challenges. By definition, Strengths (S) and Weaknesses (W) are considered to be internal factors for an industry over which the researchers have some measure of control. SWOC Analysis is the most renowned tool for audit and analysis of the overall strategic position of the industry and its environment. Its key purpose is to identify the strategies that will create an industry specific business model that will best align the available resources and capabilities to the requirements of the environment in which the firms in an industry operates. SWOC is the foundation for evaluating the internal potential and limitations and the probable/likely opportunities and threats from the external environment. It views all positive and negative factors inside and outside of an industry that affect the success. A consistent study of the environment in which the firm operates helps in forecasting/predicting the changing trends and also helps in including them in the decision-making process of the organization. The strength, weakness, opportunities, and challenges of a given industry in terms of various factors like its products/services, the employment created, business sustainability, the environmental effect, the associated supporting industries, the usage of technology, ability of using online business models etc. in terms of challenges to present business and opportunities for future business are to be analysed.

(9) Product/Service Analysis:

The quality, suitability, durability, features, and acceptability of a product or service by its customers and further possible innovations are the main essences of product/service analysis.

(10) Investment Analysis: 
While analysing an industry in terms of investment in the stock market there are two very common methodologies used, fundamental analysis and technical analysis. As with any investment strategy there are advocates and detractors of each approach. This article will explain both methodologies so that you can clearly understand the process of fundamental analysis vs. technical analysis. Fundamental analysis is the approach whereby one tries to calculate the intrinsic value of a stock by looking at the basic economic factors, the fundamentals, which would impact its value. Relevant factors that will be looked at include:

- Revenues, expenses and income

- Growth prospects for the company

- The competitive factors the company faces

- Expected return on equity or assets in the industry

The goal of this analysis is to establish a value for the stock that would factor in all of these underlying factors. As the approach doesn't look at short term pricing and trading swings this is considered a long term investment approach, as it may take time for the intrinsic value to be realized. As these factors in forward looking expectations this methodology is considered to build a valuation based on backward and forward looking information.

Technical analysis is an investment methodology that evaluates investments purely on the market activity surrounding them, with no looking to the actual operations or value of the company itself. Relevant factors that will be looked at include:

- Historical pricing of the shares

- Trading volumes over time

- Industry trading trends

The goal of this analysis is to capitalize on pricing opportunities and trends that can be identified in the market activity around each share. As the methodology is purely based on historical market activity this is considered to be a backward looking methodology.

(11) Automation \& Labour Requirement Analysis :

Analysis of industrial automation systems already adopted in a given industry and their impact on the job market, reduction in cost, initial capital investment, and the quality of the products/services. Based on the analysis, one can determine a given industry as capital intensive or labour intensive. The researcher can also study the impact of future changes in the technology on the relevance and the economic performance of the given industry.

\section{(12) People perception Analysis}

The perception about the given industry, its products or services, usefulness of that industry to the society, environmental effect of that industry, contribution of that industry to the economical change and social change of the country. The crucial factors like employment created by the industry, the industrial green strategy, the environmental degradation created by the industry, and the contribution of that industry to overall solution of basic problems of the mankind are to be analysed.

(13) Size of the Industry \& Total Contribution to the Economy :

Analysing the size of the given industry, the number of companies functioning, the contribution to economy and GDP by the industry, what types of workforces required with diverse skills and education levels, what is the average salary of this industry comparing to average salary of other industries in the country etc.

\section{(14) Market Demand Analysis:}

Industries use market demand analysis to understand how much consumer demand exists for a product or service in a given industry. This analysis helps to determine if the companies in a given industry can successfully enter a market and generate enough profits to advance its business operations. While several methods of demand analysis may be used, they usually contain a review of the basic components of an economic market. Market demand analysis contains market identification, product niche, growth potential, and competition analysis. Market demand indicates the total demand of specific products in an industry.

(15) Opportunity Analysis:

The various opportunities in a given industry for its products and services, growth and expansion, improved business models, better margins, brand building, economy of scale etc. have to be 
analysed. The success of opportunity analysis involves competitive analysis, demand forecasting, targeted marketing, technology analysis, and marketing research.

(16) Government Policy Analysis :

Government policies can have a major impact on the competitiveness and profitability of industries. This section should focus on how the government policies on a given industry are supported or hindered its performance and growth. The ability of an industry to influence the local government and supporting industries in terms of mobilising the resources, getting preference in subsidy, decreasing the tax to be imposed, and attracting new investments from global players, and providing single window clearance for permissions etc. have to be analysed.

(17) Industry Contribution \& Employment Generation Analysis :

Industry contribution for fulfilling the basic needs of the people of the country, the luxurious aspiration of the people, contribution to improve the GDP of the country, contribution towards creating employment, supporting other industries, and contribution towards foreign export can be analysed.

(18) Top leading Companies in an Industry \& their Strategies :

The researcher can also study and identify the top leading companies in a given industry and their contribution towards improvements in the economy of the country. The analysis can also include the study of various strategies used by such companies in a given industry. These strategies may include differentiation/red ocean strategy, monopoly/blue ocean strategy, sustainability/green ocean strategy, survival/black ocean strategy, and mixed/white ocean strategy.

(19) Latest Industrial Developments:

Studying, and analysing short time and long time changes/developments in an industry based on changes in business models, changes in technology, changes in people aspirations, and changes in local/ country Govt. policies, may affect the overall performance of the given industry.

(20) Cross-industry Analysis :

The cross-industry analysis focuses on comparing the business features on various inter-related industries in horizontal (within an industry sector) and vertical (in different industry sector) integrated schemes. This also includes how to identify, evaluate, and implement corporate investment projects, capital budgeting, financing, risk and return, and weighted average cost of capital concepts and processes to maximize shareholder value and minimize risk in a given industry.

(21) Market Size:

Determining the market size of a given industry by collecting required data and analysing such data for a given period and forecasting the market share of the industry for next period using various operational research models like Markov analysis is also a method of analysing a given industry's performance. The data related to the market size of an industry can be collected to free resources on the web, Government sources, Trade associations, Financial Services Firms, and Online Data Providers.

(22) Information Technology Implementation :

Strategic grid model can be used to analyse the stages of information technology adoption in various companies of an industry. Depending upon the nature of products/services and their tangibility/intangibility, opportunity to use information technology supported e-business models in a given industry to decrease the cost of doing business and for global marketing [38-39].

(23) Studying Industry Innovations using Six Thinking Hats :

Six thinking hats is a lateral thinking technique for solving any given problem in an industry innovatively [40-44].

\section{CASE STUDY BASED ON INDUSTRY ANALYSIS :}

Industry analysis may be based on Product/Service analysis, Technology analysis, Market demand analysis, Competitor analysis, Stock market investment analysis, Present and future demand analysis, Industry performance with time analysis, Country based geographical location analysis, Leadership analysis, Industry resources analysis, Industry sector analysis, Industry breakthrough analysis, Industry growth \& growth potentials analysis, Overall financial performance in an industry, Challenges and Opportunities, Investment attractiveness, Environmental analysis, Analysis on strategies to be followed for success including competitive strategies, blue ocean strategies for 
monopoly, green ocean strategies for sustainability, and black ocean strategies for survival etc. A researcher can study a given industry based on one or more objectives and search for an issue to be addressed or a problem to be solved with the optimum solution. He can also study various incidents happened in a given industry in a systematic way (for example, chronological order) which has made the drastic change in the performance or contribution to the society. These systematic studies on an identified issue or problem faced by an industry and its consequence on business environment can be published as a case study article in journals/books.

\section{INDUSTRY FORCES AND TRENDS :}

It is interesting to know various forces affecting the growth and performance of an industry. The political, environmental, social, and technological issues on the performance of a given industry in terms of production, marketing, strategies, profit, expansion, customer satisfaction, etc. can be analysed by means of PEST analysis. PEST analysis discloses the ability of an industry to sustain in highly competitive business arena worldwide. Under political factors, the role the government plays in a given industry is a subject of analysis. Under economic factors, one has to determine how the industrial performance affects the economy of both a local and national level. Under social factors, the researcher can study what the relevant changes in matters like lifestyle trends, demographics, consumer attitudes, buying patterns and opinions of the people due to that industry. The impact of changing technological trends on the sustainability and growth of the given industry can be analysed.

\section{INDUSTRIAL COMPETITIONS :}

Once the researcher gives an idea of the important trends and paradigm shifts in a given industry, they have to start finding the major competitors (both direct and indirect) in that industry. While comparing the performance of competitors, the researcher can mention things like their annual profits, market share, and distinct competitive advantage. For a given industry, it's much easier to find information on public companies than private companies, but it's always a good idea to do as much background research as possible.

As per Michael Porter's Generic Competitive Strategy, which states three routes for standing out from the competition including (i) cost leadership- having the capacity to scale operations in order to offer lower prices than the majority of the players in an effort to maximize profits, (ii) Differentiationwhere the product or service offered by a company within a given industry are something distinct than those of the current cost leaders in the industry and banks on standing out based on the "newness" factor, (iii) Market segmentation where the researcher focus on a very specific or "niche" target market and focus on building traction with a smaller segment of customers first before moving on to the bigger customer base. Based on business model used in a given industry, companies can compete on (i) Newness - Satisfying a previously undiscovered need or want with no similar offering, (ii) Performance - A company built something that is incrementally faster or better than what exists in the marketplace, (iii) Customization - Tailoring the offerings to each individual customer or customer segment, (iv) Design - Offerings are markedly better designed or stands out from the others, (v) Price - A particular company in a given industry offers the same thing as everyone else at a lower price, (vi) Cost reduction - Through a company strategy customers save money, (vii) Risk reduction - A company help to reduce the risk of its customers take when purchasing its offers, (viii) Accessibility - Tapping into a previously underserved or never served market, (ix) Convenience - A company in a given industry made something that's much easier to use than whatever else is in the marketplace.

\section{LEARNING OPPORTUNITIES BASED ON INDUSTRIAL ANALYSIS :}

A case study based management research and teaching pedagogy are adopted by many business schools with the belief that it is a most powerful way to study and learn new lessons required to identify, understand, and solve the problems in the process of managing and leading the organizations. Analysing business cases of industries force students to grapple with exactly the kinds of situations, decisions, and dilemmas managers confront every day. Industry analysis is a very important area in business management education where students and researchers can study various aspects of an industry and its components to enrich their knowledge in the core area of business 
including organizational management, environmental management, functional areas of business, strategic management, new idea creation as well as effective decision making. The issues or problems identified in a given industry and the efforts made by organizations to handle such issues or solve such problems are learning opportunities for students and researchers in Business management institutions.

\section{PUBLICATIONS BASED IN INDUSTRIAL ANALYSIS :}

Industry analysis articles can be published as research/case study articles in peer-reviewed journals provided they create some new knowledge based on analysing one or more issues in a given industry and interpret the results or suggest recommendations on possible decisions to be taken by the managers. In case study based research papers, the researchers can critically analyse the decisions taken by various companies, their managers/executives, in various situations and comment on the optimality of such decisions. Usually, the industry analysis paper is of exploratory in nature rather empirical in nature. Collection of required data by means of developing questionnaires on a selected industry and analysing them based on identifying inter-relation between specific variables leads to empirical research. It is always suggestible to a new researcher to take up one or more industry analysis for initial publications before stepping into empirical research on an identified topic.

\section{CONCLUSIONS :}

Business case writing and publication based on industry analysis is one of the strategies of the researchers in many business schools to create new knowledge about industries. Adding industry analysis in the curriculum for offering credit will enhance the academic involvement of the research student in industry affairs and hence will improve the amount of industry-institute interaction. In this paper, we have discussed how to make industry analysis as research-based case studies in business management to publish them in peer-reviewed journals. The detailed study on Industry Analysis as Business Research Methodology, and various possibilities of Types of Industry Analysis including Industry Sector Analysis, Industry Trend Analysis, Environmental Analysis, Competitor Analysis, Alternative Product/service Analysis, Financial Performance Analysis, Industry ABCD Analysis, Industry SWOC Analysis, Product/Service Analysis, Investment Analysis, Automation \& Labour Requirement Analysis, People perception Analysis, Size of the Industry \& Total Contribution to the Economy, Market Demand Analysis, Opportunity Analysis, Government Policy Analysis, Industry Contribution \& Employment Generation Analysis, Top Leading Companies in an Industry \& their Strategies, Latest Industrial Developments, Cross-industry Analysis, and Market Size, Information Technology Implementation, and Analysis of possible innovations in an industry using six thinking hats are discussed. Issues like how to develop business case study using industry analysis and publication of such industry analysis as case studies are also discussed.

\section{REFERENCES :}

[1] Fidel, R. (1984). The case study method: a case study. Library and Information Science Research, 6(3), 273-288.

[2] Yin, R. K. (1992). The case study method as a tool for doing evaluation. Current Sociology, 40(1), 121-137.

[3] Stake, R. E. (1978). The Case Study Method in Social Inquiry 1. Educational researcher, 7(2), 58.

[4] Stake, R. E. (1983). The case study method in social inquiry. In Evaluation models (pp. 279-286). Springer Netherlands.

[5] Flyvbjerg, B. (2006). Five misunderstandings about case-study research. Qualitative inquiry, 12(2), 219-245.

[6] Gerring, J. (2004). What is a case study and what is it good for?. American political science review, 98(02), 341-354. 
[7] Runeson, P., \& Höst, M. (2009). Guidelines for conducting and reporting case study research in software engineering. Empirical software engineering, 14(2), 131.

[8] Bowen, G. A. (2009). Document analysis as a qualitative research method. Qualitative research journal, 9(2), 27-40.

[9] Noor, K. B. M. (2008). Case study: A strategic research methodology. American journal of applied sciences, 5(11), 1602-1604.

[10] Tellis, Winston, (1997). Introduction to Case Study. The Qualitative Report, Volume 3, Number 2, July. (http://www.nova.edu/ssss/QR/QR3-2/tellis1.html).

[11] Zaidah Zainal (2007). Case study as a research method, Jurnal Kemanusiaan bil.9, 1-6.

[12] Yin, R.K., (1984). Case Study Research: Design and Methods. Beverly Hills, Calif: Sage Publications.

[13] McDonough, J. and McDonough, S., (1997). Research Methods for English Language Teachers. London: Arnold.

[14] Aithal, P. S. \& Suresh Kumar, P. M. (2017). Challenges and Opportunities for Research \& Publications in Higher Education. International Journal of Scientific Research and Modern Education (IJSRME), 2(1), 42-49. DOI: http://dx.doi.org/10.5281/ZENODO.400619.

[15] Aithal, P. S. (2017). An Effective Method of Developing Business Case Studies based on Company Analysis, International Journal of Engineering Research and Modern Education (IJERME), 2(1), 16-27. DOI: http://dx.doi.org/10.5281/ZENODO.400579.

[16] Lee S. F., and Ko, A. S. O., (2000). Building Balanced Scorecard with SWOT Analysis, and Implementing, Sun Tzu's The Art of Business Management Strategies on QFD Methodology. Managerial Auditing Journal, 15 (1-2), 68-76.

[17] Aithal, P. S. \& Suresh Kumar, P. M. (2015). Applying SWOC Analysis to an Institution of Higher Education. International Journal of Management, IT and Engineering (IJMIE), 5(7), 231247, DOI : http://doi.org/ 10.5281/zenodo.163425.

[18] Weihrich, H. (1982). The TOWS matrix-A tool for situational analysis. Long range planning, 15(2), 54-66.

[19] Melanie Allen. (2001). What can you review? An introduction to PESTLE analysis : Select Knowledge Limited., UK,.(pg 54 - 65).

[20] Ho, J. K. K. (2014). Formulation of a systemic PEST analysis for strategic analysis. European academic research, 2(5), 6478-6492.

[21] Aithal, P. S., (2016). Study on ABCD Analysis Technique for Business Models, business strategies, Operating Concepts \& Business Systems, International Journal in Management and Social Science, 4(1), 98-115. DOI : http://doi.org/10.5281/zenodo.161137

[22] Aithal, P. S., Shailashree, V. T., \& Suresh Kumar, P. M. (2015). A New ABCD Technique to Analyze Business Models \& Concepts, International Journal of Management, IT and Engineering (IJMIE), 5(4), 409 - 423. DOI : http://doi.org/10.5281/zenodo.61652.

[23] Aithal P. S., Shailashree V. T., \& Suresh Kumar P. M., Application of ABCD Analysis Model for Black Ocean Strategy, International Journal of Applied Research (IJAR), 1(10), 331 - 337. DOI: http://doi.org/10.5281/zenodo.163424.

[24] Aithal P. S., Shailashree V. T., \& Suresh Kumar P. M. (2016). ABCD analysis of Stage Model in Higher Education. International Journal of Management, IT and Engineering (IJMIE), 6(1), 1124. DOI: http://doi.org/10.5281/ zenodo.154233. 
[25] Aithal P. S., Shailashree V. T., \& Suresh Kumar P. M. (2016). Analysis of NAAC Accreditation System using ABCD framework, International Journal of Management, IT and Engineering (IJMIE), 6(1), 30-44, DOI: http://doi.org/10.5281/zenodo.154272.

[26] Aithal P. S., Shailashree V. T., \& Suresh Kumar P. M. (2016).Application of ABCD Analysis Framework on Private University System in India. International Journal of Management Sciences and Business Research (IJMSBR), 5(4), 159-170. DOI :http://doi.org/10.5281/zenodo.161111.

[27] Aithal P. S., Shailashree V. T., \& Suresh Kumar P. M., (2016). The Study of New National Institutional Ranking System using ABCD Framework. International Journal of Current Research and Modern Education (IJCRME), 1(1), 389-402. DOI: http://doi.org/10.5281/zenodo.161077.

[28] Shubhrajyotsna Aithal, \& Aithal P. S., (2016), ABCD analysis of Dye doped Polymers for Photonic Applications, IRA-International Journal of Applied Sciences, 4(3), 358-378. DOI: http://doi.org /10.5281/zenodo.155103.

[29] Aithal, P. S. \& Suresh Kumar, P. M. (2016). CCE Approach through ABCD Analysis of 'Theory A' on Organizational Performance. International Journal of Current Research and Modern Education (IJCRME), 1(2), 169-185. DOI: http://dx.doi.org/10.5281/zenodo.164704.

[30] Varun Shenoy, \& Aithal P. S., (2016). ABCD Analysis of On-line Campus Placement Model, IRA International Journal of Management \& Social Sciences, 5(2), 227-244. DOI: http://dx.doi.org/10.21013/jmss.v5.n2.p3.

[31] Aithal, P. S., Shailashree V. T \& Suresh Kumar P. M., (2016). Analysis of ABC Model of Annual Research Productivity using ABCD Framework. International Journal of Current Research and Modern Education (IJCRME), I(1), 846-858. DOI : http://doi.org/10.5281/zenodo.62022.

[32] Aithal, P. S. (2017). ABCD Analysis of Recently Announced New Research Indices. International Journal of Management, Technology, and Social Sciences (IJMTS), 1(1), 65-76. DOI: http://doi.org/10.5281/zenodo.583644.

[33] Aithal, P. S. (2017). Factor Analysis based on ABCD Framework on Recently Announced New Research Indices, International Journal of Management, Technology, and Social Sciences (IJMTS), 1(1), 82-94. DOI: http://dx.doi.org/10.5281/zenodo.584105.

[34] Porter, M. E. (1985), Competitive Advantage: Creating and Sustaining Superior Performance. New York: The Free Press.

[35] Porter, M.E. (2008). The Five Competitive Forces That Shape Strategy. Harvard Business Review. Available at: http://hbr.org/2008/01/the-five-competitive-forces-that-shape strategy.

[36] Dobbs, E. M. (2014). Guidelines for applying Porter's five forces framework: a set of industry analysis templates. Competitiveness Review, 24(1), 32-45.

[37] Drake, P. P., \& Fabozzi, F. J. (2010). Cash-Flow Analysis. Handbook of Finance.

[38] Beaumaster, S. (1999). Information Technology Implementation Issues: An Analysis. https://vtechworks.lib.vt.edu/handle/10919/27177. Referred on 07/03/2017.

[39] Aithal, P. S. (2015). Concept of Ideal Business \& its Realization Using E-Business Model. International Journal of Science and Research (IJSR), 4(3), 1267-1274. DOI : http://doi.org/10.5281/zenodo.61648.

[40] De Bono, E. (1999) Six Thinking Hats, Back Bay Books, New York .

[41] Govind Sharma, Six Hats Thinking, its analysis and practically used example, http://blog.simplycareer.net/2013/05/six-hats-thinking-its-analysis-and.html. 
[42] Aithal, P. S., Shailashree V. T. \& Suresh Kumar P.M. (2016). Factors \& Elemental Analysis of Six Thinking Hats Technique using ABCD Framework. International Journal of Advanced Trends in Engineering and Technology (IJATET), 1(1), 85-95. DOI : http://doi.org/10.5281/zenodo.240259.

[43] Aithal, P. S. \& Suresh Kumar, P. M. (2016). Using Six Thinking Hats as a Tool for Lateral Thinking in Organizational Problem Solving. International Journal of Engineering Research and Modern Education (IJERME), 1(2), 225-234. DOI: http://dx.doi.org/10.5281/ZENODO.198724.

[44] Aithal, P. S. \& Suresh Kumar, P. M. (2017). Lateral Thinking in Managerial Decision Making Through Six Thinking Hats Technique, International Journal of Scientific Research and Modern Education (IJSRME), 2(1), 53-58. DOI: http://dx.doi.org/10.5281/ZENODO.438149. 